\title{
GLOMALIN, CARBON, NITROGEN AND SOIL AGGREGATE STABILITY AS AFFECTED BY LAND USE CHANGES IN THE HUMID FOREST ZONE IN SOUTH CAMEROON
}

\author{
FoKom, R. ${ }^{1}{ }^{*}$ - TeUgWA Mofor, C. ${ }^{1}$ - NANA WAKAM, L. ${ }^{1}$ - NGONKEU MEGAPCHE, E.L. ${ }^{2}-$ \\ TCHAMENI, S. ${ }^{1}-$ NwAGA, D. ${ }^{3}-$ RILlig, C.M. ${ }^{4}-$ AMVAM Zollo, P.H. ${ }^{1}$ \\ ${ }^{I}$ Biochemistry Department, Faculty of Science University of Yaoundé I. \\ PO Box 00812 Yaoundé Cameroon \\ ${ }^{2}$ Institute of Agricultural Research for Development (IARD \\ ${ }^{3}$ Laboratory of Soil Microbiology, \\ Biotechnology Centre and Plant Biology Department of plant biology, Faculty of Science \\ University of Yaoundé I. PO Box 00812 Yaoundé Cameroon \\ ${ }^{4}$ Freie Universitaet Berlin \\ Plant Ecology, Altensteinstr. 6, D- 14195 BERLIN, Germany \\ *Corresponding author \\ e-mail:rfokom@gmail.com
}

(Received 21 ${ }^{\text {st }}$ May 2011; accepted $2^{\text {nd }}$ September 2013)

\begin{abstract}
Arbuscular mycorhizal fungi (AMF) produce a glycoprotein (glomalin) important for soil structure, fertility and therefore plant nutrition which can be used to evaluate the impact of agricultural practices on soil quality across many land use systems. In the present study, its influence was investigated on soil fertility and aggregation in 3 different land use systems of the humid forest zone of southern Cameroon. Soils were sampled at $10 \mathrm{~cm}$ depth from 03 native forest, 03 fallow and 03 continuous growing fields systems at Metet (South Cameroon) for the determination of easily extractable glomalin (EEG), total glomalin (TG), carbon $(\mathrm{C})$, nitrogen $(\mathrm{N})$ and soil water stable aggregate of 1-2 mm diameter $\left(\mathrm{WSA}_{1-2 \mathrm{~mm}}\right)$. Results showed that both EEG and TG concentrations significantly decreased $(\mathrm{P}<0.01)$ from the forest to the growing field, via the fallow system. The rate of EEG decrease was $29.82 \%$ and $38.35 \%$ in the fallow and the growing field system compared to the forest system, respectively. For TG, the decrease rate was $16.65 \%$ to $46.04 \%$ for the fallow and the growing field system compare to the forest system respectively; while $\mathrm{C}, \mathrm{N}$, and organic matter $(\mathrm{OM})$ did not changed significantly. The proportion of $\mathrm{C}, \mathrm{N}$ and $\mathrm{OM}$ were $93.6 \%, 88.3 \%, 93.7 \%$ for the growing field system compared to the forest system respectively. The $\mathrm{WSA}_{1-2 \mathrm{~mm}}$ decreased from the forest to fallow and growing field systems, with respective rates of $19.69 \%$ and $32.81 \%$. There was high positive correlation between $\mathrm{C}, \mathrm{N}$ and EEG $\left(\mathrm{r}^{2}=0.76,0.55 ; \mathrm{P}<0.01\right)$, suggesting the possible implication of glomalin to soil stock of $\mathrm{C}$ and $\mathrm{N}$. Likewise, the high positive correlation between TG and $\mathrm{WSA}_{1-2 \mathrm{~mm}}\left(\mathrm{r}^{2}=0.64, \mathrm{P}<0.01\right), \mathrm{C}$ and $\mathrm{TG}\left(\mathrm{r}^{2}=\right.$ $0.84, \mathrm{P}<0.05), \mathrm{OM}$ and $\mathrm{WSA}_{1-2 \mathrm{~mm}}\left(\mathrm{r}^{2}=0.57, \mathrm{P}<0.01\right)$ as well as OM and TG $\left(\mathrm{r}^{2}=0.88, \mathrm{P}<0.01\right)$ suggests that glomalin, $\mathrm{C}$ and $\mathrm{N}$ may contribute to the formation of $\mathrm{WSA}_{1-2 \mathrm{~mm}}$, and thereby promote the build up of soil structure. These results highlight the view that glomalin can be used as an indicator of soil fertility in this region and should be consider as a criteria when define agricultural management strategies. Keywords: glomalin, soil stable aggregate, arbuscular mycorhizal fungi, soil fertility
\end{abstract}

\section{Introduction}

The conversion of natural ecosystems to agriculture is known to cause large losses of soil organic carbon, but these losses also depend on tillage and cropping practices (Ogle and al., 2005; Bayer and al., 2006; Dolan and al., 2006). The decrease of soil fertility 
from the native and stable system (forest) to the unstable system (growing field) generally observed during this conversion lead to the decrease of crop production in tropical zones. This is mostly due to the mineralisation of organic matter and the modification of the cropping system. The ability of soil to enable adequate crop yield in this system is perceived as depending on the duration of the fallow (Guillemin, 1956; Beets, 1990). Traditionally, the productivity in the tropical zones relies on combining long fallows and specific cropping systems, where nutrient demands of crops are covered through weathering, biological symbiosis like nitrogen fixation for legumes and arbuscular mycorhizal fungi (AMF). Over several cycles of cropping, the cultivation practices lead to the modification of soil biological and physicochemical properties. An example includes destruction of soil aggregates, particularly those of 1 to $2 \mathrm{~mm}$ diameters which are very sensitive to short length perturbations (Kemper and Rosenau, 1986). For a few decades, increasing population density in the humid forest regions such as southern Cameroon and the subsequent increasing demand for food forced farmers to shorten fallow duration, hence jeopardizing the sustainability of this farming system (Eyasu and Scoones, 1998). This situation accelerates soil exploitation by farmers and, thereby increasing land degradation and decreasing food production. Consequently, farmers permanently seek new and more fertile areas to improve their food production. This continuous destruction of the forest promotes climate change, lost of biodiversity and thereby, raising environmental problems. Therefore, there is need to promote safer methods such as use of plant symbiots. For example, AMF, a widespread plant symbiont with multiple influences on terrestrial plant communities and ecosystem processes, can contribute to slow down yield decrease over many crop cycles by maintaining soil structure (Rillig, 2004). This is because they have a variety of ecological functions, such as improvement of relatively immobile nutrients uptake by the plant (Smith and Read, 1997; Feng and al., 2002), protection of plant roots from pathogens (Newsham and al., 1995; Declerck and al., 2002) and alleviation of plant abiotic strees such as drought and aluminium toxicity (Bothe and al., 2001). Research on ecological composition and functions of AMF communities has mostly been conducted in temperate soils (Helgason and al.,1998; Oehl and al., 2003) and generally indicate higher AMF diversity in forest than in agricultural soils (Helgason and al., 1998; Alguacil and al., 2008). The role of AMF for plant nutrition and protection is now well established elsewhere in the world. Its roles on soil aggregation, an important physical property of soil, have recently received increased attention but remain not well elucidated, especially in tropical soils (Rillig and Mummey, 2006). This increased attention has been accelerated by the discovery of the soil glycoprotein named glomalin-related soil protein (glomalin in this paper) (Wright and al., 1996; Rillig, 2004), an $N$-linked glycoprotein (Wright and Upadhyaya, 1998). The description of this protein was intensified by its sequencing and the genes that code for it (Gadkar and Rillig, 2006). Glomalin is present in soils in appreciable amount, persistent and generally associated with the insoluble humus or mineral fractions in soils (Wright and Upadhyaya 1996). The amount of carbon (C) and nitrogen (N) in glomalin in tropical soils has been measured as $37 \%$ and $4 \%$, respectively, representing 3 and $5 \%$ of soil carbon and nitrogen pools, respectively (Lovelock and al., 2004). With its adhesive properties, this soil glycoprotein act by joining fine soil particles to generate aggregates that are very important for soil aeration and drainage (Wright and Upadhyaya, 1996). The correlation between soil aggregation, glomalin concentration and land use is well established in many ecological regions across the world but to the best of our 
knowledge, there is no data related to the humid tropical region of Africa up to dates. As such, we aimed at examining the influence of three different land uses on soil glomalin, $\mathrm{C}, \mathrm{N}$ concentration and soil aggregate stability in the humid forest zone of southern Cameroon, and understanding the contribution of these parameters to the formation of aggregate and soil structure.

\section{Materials and methods}

\section{Site description and sampling}

The study was carried out in three land used systems including 03 forests, 03 fallows and 03 growing fields. The 3 plots of forest systems were abandoned for at least 40 years and, are predominantly covered by 03 three species including: Combretodendron macrocarpum, (Recythidaceae) Piptadeniastrum africanum (Mimosaceae) and Disternonanthus benthamianus (Cesalpiniaceae). The three plots of fallow systems were abandoned by farmers for 5 years. Each of the three fallows plots was covered by wild species of plants dominated by the crop Chromonaela odorata at the beginning of this work. The growing fields were under a mixed cropping system since two consecutive years. For the first years, each plot received two cycles of groundnuts (Arachis hypogea) and maize (Zea mays) intercropped with cassava (Manioc esculenta) and plantain banana (Musa sp.) plant. The year after, farmers stopped planting groundnuts and maize and follow the growth of cassava and banana until harvest. It is important to note that in this zone, farmer did not usually use mineral fertiliser during the agricultural activity. A raison for that is because fertiliser is too expensive locally. The study fields are located at Metet, $100 \mathrm{~km}$ from the capital of Cameroon (Yaoundé) $\left(38^{\circ} 51^{\prime \prime} 324 \mathrm{~N}, 94^{\circ} 47^{\prime \prime} 941 \mathrm{~W}\right)$ at $540 \mathrm{~m}$ above sea level. There are 2 dry seasons per year alternating with 2 rainy seasons. The mean annual precipitation and temperature are $1500 \mathrm{~mm}$ and $24.5^{\circ} \mathrm{C}$, respectively. The area is characterised by ferrallitic soils, classified mainly as typic kandiudult soil (Koutika and al. 2004). Soil were collected from 0 to $10 \mathrm{~cm}$ depth following a cross linking diagram at 9 points per subplots. Each individual plot per three lands used systems cover 0.1 ha and was divided in 16 subplots of $5 \times 10 \mathrm{~m}^{2}$. The location of each subplot was randomly chosen in order to cover representatively the entire plot. Samples were from $16 \times 3$ subplots under each plot that make 48 samples per individual land use system. The so collected samples were carefully mixed per individual subplot and dried at room temperature $\left(28{ }^{\circ} \mathrm{C}\right)$ in the laboratory for analysis. Data from forest, fallow and growing field systems plots was designed at the onset (mean of 48 subplots).

\section{Glomalin analysis}

Glomalin was extracted from $1 \mathrm{~g}$ of dry soil per subplot using the method described by Wright and Updahyaya in 1998. In this assay, two fractions of glomalin were made: easily extractable glomalin (EEG), this is the freshly deposited glomalin fraction which can informed on the rate of the molecules release in soil and, the total glomalin (TG), this is the total stock of glomalin in soil, i.e. the mixture of EEG and the residual fraction of the molecules. For each sample, the EEG fraction was obtained with $20 \mathrm{mM}$ citrate buffer, $\mathrm{pH} 7.0$ at $121{ }^{\circ} \mathrm{C}$ for $30 \mathrm{~min}$. The residual fraction was thereafter extracted with $50 \mathrm{mM}$ citrate buffer; $\mathrm{pH} 8.0$ at $121{ }^{\circ} \mathrm{C}$ in rounds of $60 \mathrm{~min}$. Extraction continued until the supernatant showed none of the red-brown colour typical of 
glomalin. At the end of extraction, extracts from each cycle were mixed and the mixture was centrifuged $\left(5000 \times \mathrm{g}, 4{ }^{\circ} \mathrm{C}, 10 \mathrm{~min}\right)$ to remove the remaining soil particles. The amount of glomalin in the supernatant was determined by the Bradford dye-binding assay with bovine serum albumin as the standard (Wright and Upadhyaya, 1998) and expressed as $\mathrm{mg} / \mathrm{g}$ of soil. The TG was deduced by addition of EEG and the residual fraction.

\section{Soil carbon, nitrogen and organic matter analysis}

Soil samples were previously crushed in a mortar before used for analysis. Soil carbon and nitrogen content were analysed in the Soil Chemistry Laboratory of the International Institute of Tropical Agriculture (IITA) at Yaoundé, Cameroon. Organic C was determined by chromic acid digestion followed by spectrophotometric measurement according to the procedure describe by Heanes (1984). Total $\mathrm{N}$ was determined using the wet acid digestion as described by Buondonno and al. (1995) followed by colorimetric titration according to the procedure described by Anderson and Ingram (1993). Organic matter (OM) was generated from the $\mathrm{C}$ amount using the factor 1.724 as describe by Walkley and Black (1934). Results of C, N and OM were expressed as \% of the individual element compare to the initial mass of soil.

\section{Soil aggregate stability analysis}

This part of study focused on macro-aggregates of 1-2 mm diameter, since Kemper and Rosenau (1986) reported that such aggregates are sensitive to short term management and treatment of soils (below 2 years). Therefore, all soils were pre-sieved to retain material $<2 \mathrm{~mm}$ and, stored as air-dried samples until analysis. Replicate $4 \mathrm{~g}$ samples of soil aggregates per subplot were moistened by capillary action for $10 \mathrm{~min}$. Water stability of aggregates was then measured with a wet-sieving method described by Kemper and Rosenau (1986). The percentage of $\mathrm{WSA}_{1-2-\mathrm{mm}}$ was calculated using the mass of aggregated soil remaining after wet sieving and the total mass of aggregates at the beginning of the experiment. The initial and final weights of aggregates were corrected for the weight of coarse particles using the formula: final weight $=$ initial weight - coarse particles weight. Coarse particles are fraction of soil contained in the last sieve after the manipulation.

\section{Statistical analysis}

Results were analysed using the SigmaStat 2.03 software. Differences among parameters in different fields were tested by one-way ANOVA after the equivalent test of variance was satisfied, and comparisons among means were made with the StudentNewman-Keuls test. A P value of $<0.05$ was considered significant. Pearson correlation was used to appreciate the correlation between the different parameters. Correlation was considered significant at the 0.01 levels. 


\section{Results}

\section{Variation of glomalin concentration}

The concentration of the EEG and TG in the top $10 \mathrm{~cm}$ layer of soil varied from $10.56 \pm 0.98 \mathrm{mg} / \mathrm{g}$ to $6.51 \pm 0.84 \mathrm{mg} / \mathrm{g}$ for EEG and $15.67 \pm 1.36 \mathrm{mg} / \mathrm{g}$ to $8.45 \pm 1.14$ $\mathrm{mg} / \mathrm{g}$ for TG from forest to the growing field respectively (Table 1). Concentration comparison of the EEG fraction of glomalin showed significant difference between forest system compared to the fallow systems and the continuous growing field system $(\mathrm{F}=5.387 ; \mathrm{P}<0.05)$ but no difference between the fallow and the continuous growing field system. The TG showed significant difference between the forest system, the fallow systems and the continuous cropped field systems $(\mathrm{F}=21.296$; $\mathrm{P}<0.05)$. The rate of EEG decrease in the fallow systems and the continuous growing field systems was $29.82 \%$ and $38.35 \%$ respectively compared to the forest systems. The rate of TG decrease in the fallow systems and the continuous growing field systems is $16.65 \%$ and $46.07 \%$, respectively, compared to the forest system. The proportion of EEG fraction is $67.38 \%, 56.73 \%$, and $77.04 \%$ of TG respectively in the forest systems, the fallow systems and the continuous growing field systems, suggesting that the turnover rate of EEG in the growing field system is high compared to that of the two other fields.

Table 1. Easily extractable glomalin (EEG), total glomalin (TG), soil carbon, nitrogen and organic matter concentration in the three studied land use types

\begin{tabular}{c|c|c|c|c|c|c|c}
\hline $\begin{array}{c}\text { Land use } \\
\text { system }\end{array}$ & EEG $(\mathbf{m g} / \mathbf{g})$ & $\begin{array}{c}\text { TG } \\
(\mathbf{m g} / \mathbf{g})\end{array}$ & $\mathbf{C}(\%)$ & $\mathbf{N}(\%)$ & C/N & $\begin{array}{c}\text { OM } \\
(\%)\end{array}$ & $\begin{array}{c}\text { WSA\% } \\
\mathbf{1 - 2 m m}\end{array}$ \\
\hline Forest & $10.56(0.98)^{\mathrm{a}}$ & $15.67(1.36)^{\mathrm{a}}$ & $1.56(0.02)^{\mathrm{a}}$ & $0.150(0.01)^{\mathrm{a}}$ & $10.40^{\mathrm{a}}(0.07)$ & $2.68^{\mathrm{a}}$ & $64.75(1.36)^{\mathrm{a}}$ \\
Fallow & $07.41(1.73)^{\mathrm{b}}$ & $13.06(2.32)^{\mathrm{b}}$ & $1.52(0.03)^{\mathrm{a}}$ & $0.138(0.00)^{\mathrm{b}}$ & $11.01^{\mathrm{b}}(0.15)$ & $2.62^{\mathrm{a}}$ & $52.0(4.95)^{\mathrm{b}}$ \\
Field & $06.51(0.84)^{\mathrm{b}}$ & $08.45(1.14)^{\mathrm{c}}$ & $1.46(0.05)^{\mathrm{b}}$ & $0.129(0.01)^{\mathrm{c}}$ & $11.31^{\mathrm{b}}(0.03)$ & $2.51^{\mathrm{b}}$ & $43.5(0.73)^{\mathrm{c}}$ \\
\hline
\end{tabular}

Results are expressed as the means (SD); Values followed by a different letter differ significantly among land-use types $(\mathrm{P}<0.05 ; \mathrm{n}=3 * 16$, student Newman kuhl test). $\mathrm{EEG}=$ easily extractable glomalin; $\mathrm{TG}=$ total glomalin; $\mathrm{WSA}_{1-2 \mathrm{~mm}}=$ water stable aggregates of 1 to $2 \mathrm{~mm}$ diameter; $\mathrm{C}=$ carbon; $\mathrm{N}=$ nitrogen; OM=organic matter.

\section{Variation of $C$, $N$ and organic matter}

The concentration of $\mathrm{C}, \mathrm{N}$ and organic matter in the top $10 \mathrm{~cm}$ layer of soil decreases from the forest system to the continuously growing field system (Table 1). The $\mathrm{C} / \mathrm{N}$ ratio was found to increase from the forest system to the continuous growing field system. The rate of decrease of $\mathrm{C}$ in the continuous growing field system is $6.4 \%$ compare to the forest system. The rate of decrease of $\mathrm{N}$ in the fallow system and the continuous growing field is $8 \%$ and $14 \%$ respectively compared to the forest system. The rate of decrease of $\mathrm{OM}$ in the fallow system and the continuous growing field system is $2.23 \%$ and $6.34 \%$ respectively compared to the forest system. Comparison of percentage showed significant difference between forest system and fallow system for the following parameters $\mathrm{N}$ and $\mathrm{C} / \mathrm{N}$ while no significant difference was observed between the fallow system and the forest system for $\mathrm{C}$ and $\mathrm{OM}$.

To gain some understanding on the link between the EEG fraction of glomalin, $\mathrm{C}$ and $\mathrm{N}$ concentration, we plotted $\mathrm{C}$ and $\mathrm{N}$ versus EEG (Figure $1 a$ and $b$ ). Result showed a positive correlation between EEG, $\mathrm{C}$ and $\mathrm{N}$ with the determination coefficients $\mathrm{r}^{2}=0.76$ and 0.55 respectively. 
TG versus $\mathrm{OM}$ as well as $\mathrm{C}$ were also plotted to assess the link between $\mathrm{TG}$ and organic matter, TG and $\mathrm{C}$ in soil of the three different land used systems (Figure $2 a$ and $b$ ). Results also showed a positive correlation between the TG and the soil OM and C concentration in the three land used systems. The determination coefficients were $r^{2}=$ 0.88 and 0.84 respectively.
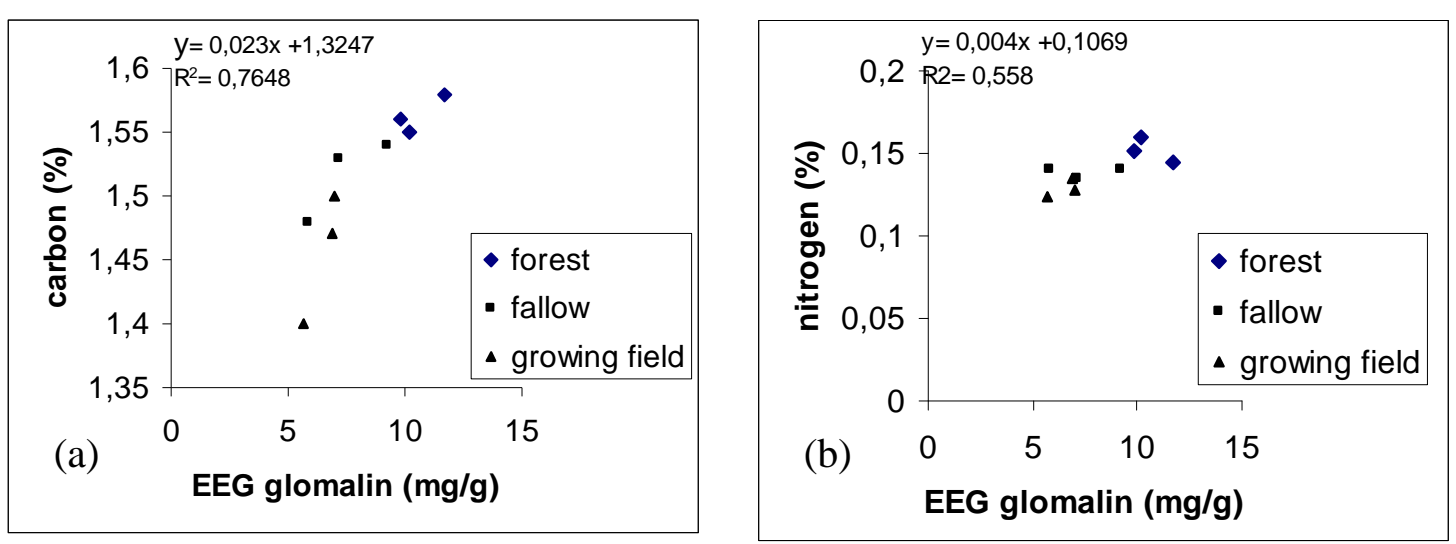

Figure 1. Relationship between carbon and EEG (a), nitrogen and EEG $(b)$ in three land use systems of the humid forest of the South region of Cameroon (forest, fallow, field) $P<0.01$ )

(student Newman Kuhl test)

\section{Variation of water stable aggregate}

The percentage of $\mathrm{WSA}_{1-2 \mathrm{~mm}}$ in the top $10 \mathrm{~cm}$ layer of soil decreased from the forest system $(64.75 \%)$ to the continuous growing field system $(43.5 \%)$, via the fallow system $(52.0 \%)$ (Table 1). The rate of $\mathrm{WSA}_{1-2 \mathrm{~mm}}$ decrease in the fallow and the continuously growing field system is $19.69 \%$ and $32.81 \%$, respectively compare to the forest system. Comparison percentage of $\mathrm{WSA}_{1-2} \mathrm{~mm}$ showed significant difference between the forest system, the fallow system and the continuous growing field system $(\mathrm{F}=33,105 ; \mathrm{P}<0.001)$. The TG fraction also correlated positively with $\mathrm{OM}\left(\mathrm{r}^{2}=0.57\right.$ (Figure $3 a$ ) and $\mathrm{WSA}_{1-2 \mathrm{~mm}}\left(\mathrm{r}^{2}=0.64\right)$ (Figure $\left.3 b\right)$.

\section{Discussion}

Both EEG and TG has been evaluated in three different land use types in this study, representative of the various field systems in the humid forest zone of the south region of Cameroon. The concentration of EEG and TG significantly decreased from the forest system to fallow system and then growing field system. In each system individually, the concentration of glomalin is higher than the amount of $2 \mathrm{mg} / \mathrm{g}$ of soil found in Texas soil (Wright and Upadhyaya, 1998). However, only the concentration of glomalin in the forest and fallow system is higher than $11.24 \mathrm{mg} / \mathrm{g}$ reported in the assessment of mycorhizal parameters for the $1-2 \mathrm{~mm}$ size class of soil aggregates in green house experiment (Rillig and al., 2005). Further study on AMF diversity is necessary to understand whether new strains able to improve the production of glomalin exist in the soil of this region. Nevertheless, the decrease of glomalin concentration from the forest to fallow and then growing field systems is in accordance with the observation of 
Bedini and al., (2006) who note the decrease of glomalin concentration from native forest to native grassland and to continuous monoculture maize field but in temperate region. The concentration of the EEG fraction assimilated to the most freshly deposited fraction by AMF through hyphae is not significantly different between the fallow and the continuous growing field system. Previous study has shown that soil disturbance decrease AMF population (Hamel and al., 1994; Dodd and al., 2000) with disruption of mycelia network. This might directly result to the decrease of glomalin synthesis and deposition in soil. Similar observation were made by Rillig and al., 2003 when study the less similar system (agriculture and afforested field). This glycoprotein constitutes one of the many ways plants used to restore carbon to soil (Driver and al., 2005; Zhu and Miller, 2003). In general, AMF are highly sensitive to cropping (Miller and Lodge, 1997; Rillig, 2004), mainly because of the mechanical disturbances by tillage (Wright and al., 1999; Wright and Anderson, 2000; Kabir, 2005). The difference in TG concentration across the different system study can be attributed to the rate of disturbance from the forest system to the continuous growing field system, affecting AMF populations (Helgason and al., 1998, Alguacil and al., 2008). Across the three systems study, there is a positive correlation between the EEG fraction of glomalin, carbon and nitrogen concentration $(r=0.76,0.55 ; \mathrm{P}<0.01)$ (Figure la and $b$ ). This positive correlation might explain the implication of this protein to the restoration of soil stock of $\mathrm{C}$ and $\mathrm{N}$ because glomalin molecules are made with a relatively high proportion of $\mathrm{C}$ and $\mathrm{N}$ atoms.
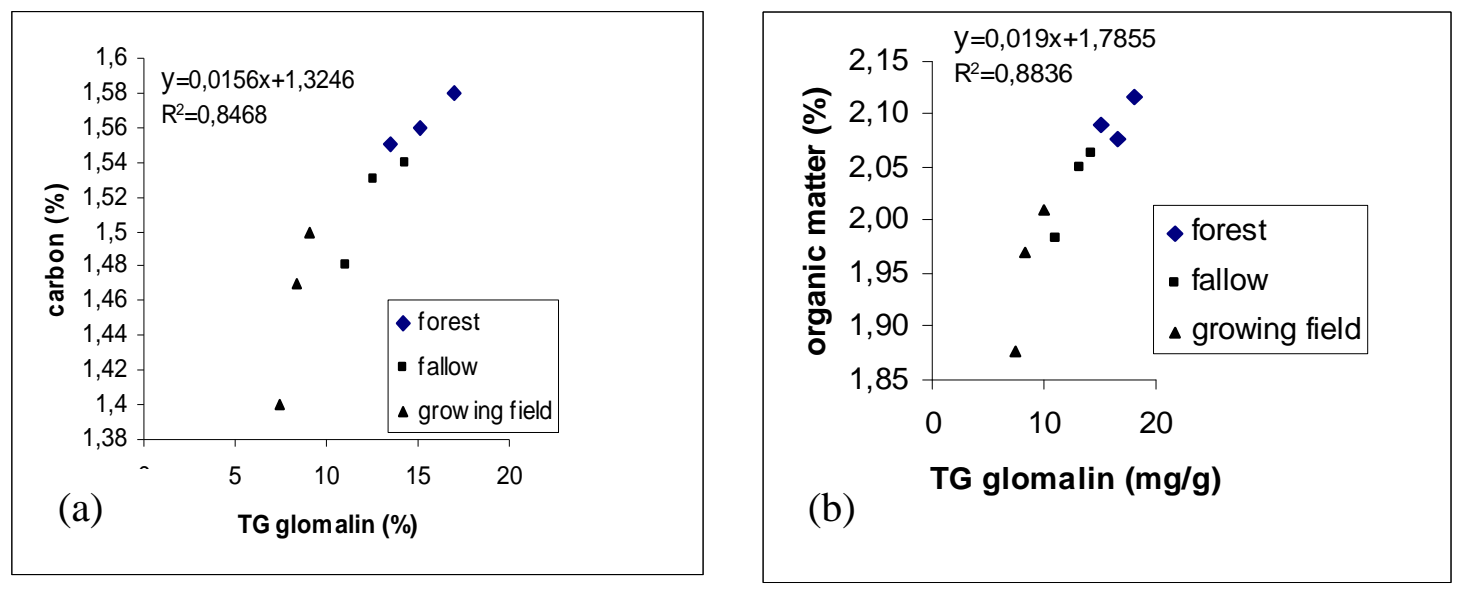

Figure 2. Relationship between carbon and $T G(a), T G$ and organic matter $(b)$ in three land use type of the humid forest of the South region of Cameroon (forest, fallow, field) $P<0.01$ (student Newman Kuhl test)

The comparison of TG soil concentration with $\mathrm{C}$ pool in the 03 different systems show a positive correlation between the two parameters $\mathrm{r}^{2}=0.84 \mathrm{P}<0.01$ (Figure $2 a$ ). This observation is in accordance with those from other studies showing strong correlation between TG and C pool in natural and cultivated soils (Rillig, 2003; Nichols and Wright, 2005). The observation suggested a possible similar rate of deposition and decomposition dynamics of the carbon and TG in soil.

We found no significant difference in OM between the forest system and the fallow system. However there is a significant difference between the above two systems and 
the continuous growing field systems. This observation support the idea that reduce soil tillage practices minimize soil disturbance and increase soil organic matter comparatively to the conventionally plowed soils (Carter, 1992; Franzluebbers and al., 1999).
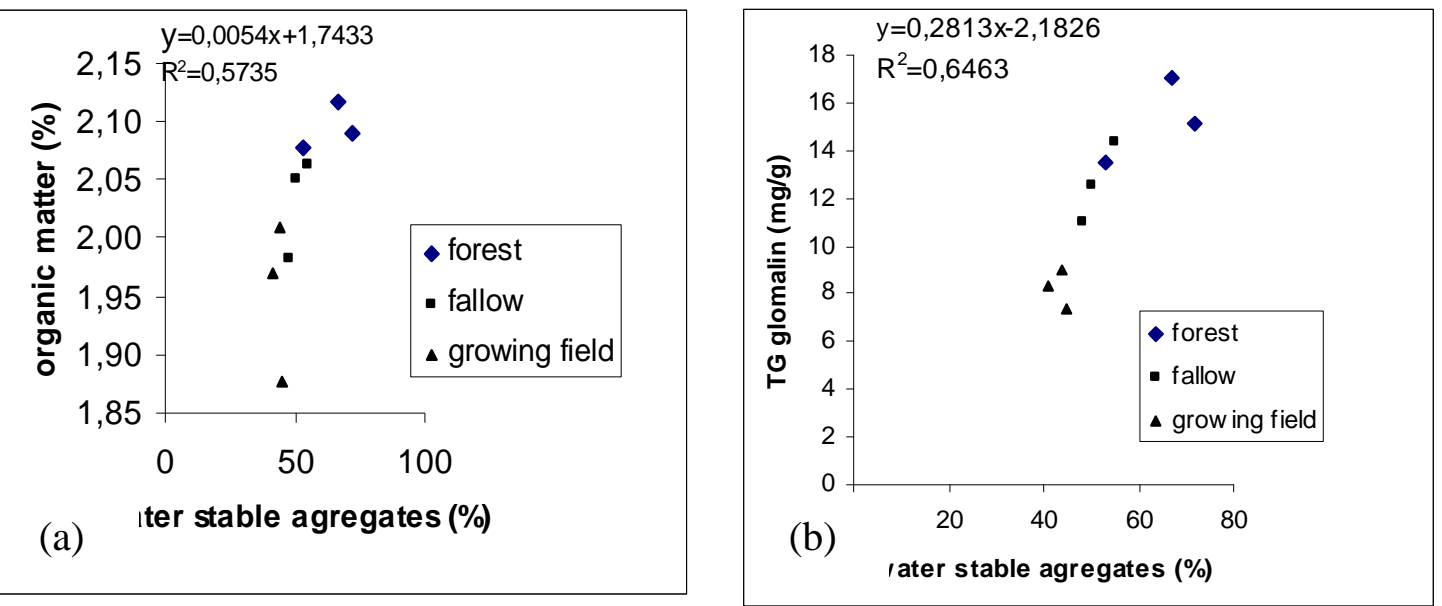

Figure 3. Relationship between water stable aggregates of 1 to $2 \mathrm{~mm}$ diameter $\left(W S A_{1-2 \mathrm{~mm}}\right)$ and organic matter $(O M)(a), T G$ and $W S A_{1-2 m m}(b)$ in three land used type of the humid forest of the South region of Cameroon (forest, fallow, field) $P<0.01$ (student Newman Kuhl test)

The comparison of the TG soil concentration with soil OM in the 03 systems studied showed a positive correlation with $\mathrm{r}^{2}=0.88 \mathrm{P}<0.01$ (Figure $2 b$ ). This observation support the view that AMF contribute directly to OM in soil by the production of extra radical hyphae (Miller and Kling, 2000; Johnson and al., 2002), and indirectly by enhancing plant growth (Varma, 1998). The direct ways used by AMF to regulate OM could be the production of the protein glomalin in a relative high concentration in soil through hyphae. This is in accordance with findings from many other studies in temperate and tropical zones of America. For examples, in a comparison of 12 acidic soils of tropical and temperate zone in America, the TG was strongly correlated with soil $\mathrm{C}$ the essential atoms found in OM $\left(\mathrm{r}^{2}=0.84\right.$; Wright and Upadhyaya, 1996). Across 37 soils representing a variety of soil types and management practices of tropical and temperate zone in America,\% soil C was correlated with the TG $\left(\mathrm{r}^{2}=0.82\right.$ and soil $\mathrm{N}$ also; Wright and Upadhyaya, 1998). The positive correlation of the TG with soil $\mathrm{C}$ supports the view that glomalin can be useful as a sensitive indicator of soil $\mathrm{C}$ changes observed during land use practices in the humid forest zone of the tropical region as proposed Rillig (2003) in his study in America. Following this finding, it is clear that TG substantially contributes to total soil $\mathrm{C}$ and $\mathrm{N}$ pools in the humid forest zone of central Africa precisely in the south region of Cameroon. This affirmation was previously proposed by Rillig and al., 2001; Lovelock and al., 2004 when they realise that 3 to $5 \%$ of total soil carbon is conserved in the glycoprotein glomalin in both tropical and temperate climates of America.

The water stable aggregate of 1-2 mm diameter $\left(\mathrm{WSA}_{(1-2 \mathrm{~mm})}\right)$, significantly decrease from the forest system to the fallow system and the continuously growing field system (Table 1). This is in accordance with the finding of Lawal and al. 2009 who showed that small macro aggregates $(0.25-2 \mathrm{~mm}$ diameter) is high under forest ecosystem, follow by 
native vegetation and arable cropping respectively in the sup humid tropical region of Nigeria. Also Beare and al., (1994) demonstrated that cultivation of soils will lower the structural stability relative to the no tillage soil. Nevertheless, biological factors contribute to join soil particles together and are very sensitive to soil perturbations. Among the biological factors, AMF has been credited with a special importance (Rillig and Mumey, 2006), attributed to a physical effect of a network around soil particles, together with the hyphal production of significant amounts of the glycoprotein glomalin which cement soil component (Wright and Upadhyaya, 1998; Rillig and al., 2002; Nichols and Wright, 2005). In this study, the comparison of the TG, OM and the WSA $2 \mathrm{~mm}$ showed positive correlation between TG, OM with $\mathrm{WSA}_{(1-2 \mathrm{~mm})}($ Fig $3 a$, and $b$ ) with $\mathrm{r}^{2}=0.64$, and 0.57 respectively. An explanation for this observation is that tillage practice breakdown existing aggregates destroyed the AMF net work, decrease glomalin deposition and organic matter in soil resulting in the decrease of aggregates formation precisely those of $1-2 \mathrm{~mm}$ diameters very sensitive to soil perturbation of short periods. This observation support the view of Wright and al 2007 in her work on glomalin in aggregate size classes from three different farming systems that there is a large proportion of glomalin (GRSP) associated with aggregate fraction of 0.5 to $2 \mathrm{~mm}$ in not tillage soil (similar to forest system in this study) compare to continuous tillage soil (similar to continuous growing field in this study). This observation might point out the great contribution of glomalin and OM to the build up of soil structure and highlight the glue like properties previously attributed to glomalin and a fraction of organic matter in the soil aggregate formations (Wright and al., 2007). The relative high concentration of the glomalin in the forest systems compare to the others systems support the view that glomalin deposited in soil can stay for a very long time up to 42 years, and could represent a reasonable large influx of soil organic matter, possibly on the order of 10 to 100 grams of $\mathrm{C} / \mathrm{m}^{2}$ per year (Kathleen and Katie, 2007).

\section{Conclusion}

The prevalent of forest system may have created a significant increase in the glomalin concentration, carbon nitrogen and water stable aggregates of $1-2 \mathrm{~mm}$ diameter. The fallow system may have also created a significant increase of these parameters. The turnover rates of glomalin in the growing field system seem to be higher than the forest and fallow system. Fallow practice greatly contributes to the reconstitution of the soil by increasing glomalin concentration which may have join soil particle of $1-2 \mathrm{~mm}$. This can be supported by the high positive correlation between glomalin concentration, OM and $\mathrm{WSA}_{1-2 \mathrm{~mm}}$. Soil glomalin concentration should be an important criteria when build up agricultural management strategies in this region. Information on AMF diversity will greatly contribute to understand the relative high concentration of glomalin in the forest system, the high turnover rate of this protein in the growing field system and help to build up a new strategy to manage yield decrease in this region.

Acknowledgements. We hereby thank the International Institute of Tropical Agriculture (IITA) through the RFPP project for sample collection and Soil Chemistry Laboratory for $\mathrm{C}$ and $\mathrm{N}$ analysis, as well as the National Institute of Agriculture for Development (IRAD) for water stable aggregate analysis. We also thank Pr. M. Cavigelli for his critics. 


\section{REFERENCES}

[1] Alguacil, M.M., Lumini, E., Roldan, A., Salinas-Garcia, R.J., Bonfante, P., Bianciotto, V. (2008): The impact of tillage practices on arbuscular mycorhizal fungal diversity in subtropical crops. - Ecol. Appl. 18: 527-536.

[2] Anderson, J.M., Ingram, J.S.I. (1993): Tropical soil biology and fertility: a handbook of method. - Second edition, CAB International, the Cambrian news, Aberstwyth, United Kingdom, 221p.

[3] Bayer, C., Martin-Neto, L., Mielniczuk, J., Pavinato, A., Dieckow, J. (2006): Carbon sequestration in two Brazilian Cerrado soils under no-till. - Soil Till. Res. 86: 237-245.

[4] Beare, M.H., Hendrix, P.F., Coleman, D.C. (1994): Water-stable aggregate and organic matter fractions in conventional-and no tillage soils. - Soil Sci. Soc. Am. J. 58: 777-786.

[5] Bedini, S., Avio, L., Argese, E, Giovannetti, M. (2006): Effects of long term land use on arbuscular mycorhizal fungi and glomalin related soil protein. - Agric. Ecosyst. environ. doi: 10.1016/j.agee.2006.09.010.

[6] Beets, W.C. (1990): Raising and sustaining productivity of smallholder farming systems in the tropics. - Holland AgBe Publishing, 738p.

[7] Bothe, H., Hildebrandt, U., Ouziad, F., Landwehr, M., Nawrath, K. (2001): The colonization of plants from Central European heavy metal soils and salt marshes by arbuscular mycorrhizal fungi. - Min. Biotech. 13: 65-67.

[8] Buondonno, A., Rashad, A.A., Coppola, E. (1995): Comparing test for soil fertility. The hydrogen peroxide/sulphuric acid treatment as an alternative to the copper/selenium catalysed digestion process for routine determination of soil nitrogen-kjeldahl. Communication in soil science and plant analysis 26: 1607-1619.

[9] Carter, M.R. (1992): Influence of reduced tillage systems on organic matter, microbial biomass, macro-aggregate distribution and structural stability of the surface soil in a humid climate. - Soil. Till. Res. 23: 361-372.

[10] Declerck, S., Risede, J.M., Rufyikiri, G., Delvaux, B. (2002): Effects of arbuscular mycorrhizal fungi on severity of root rot of bananas caused by Cylindrocladium spathiphylli. - Plant. Pathol. 51: 109-115.

[11] Dodd, J.C., Boddington, C.I., Rodriguez, A., Gonzalez-Chavez, C., Mansur, I. (2000): Mycelium of arbuscular mycorrhizal fungi (AMF) from different genera: Form, function, and detection. - Plant. soil. 226: 131-135.

[12] Dolan, M.S., Clapp, C.E., Allmaras, R.R., Baker, J.M., Molina, J.A.E. (2006): Soil organic carbon and nitrogen in a Minnesota soils as related to tillage, residue and nitrogen management. - Soil. Till. Res. 89: 221-231.

[13] Driver, J.D., Holben, W.E., Rillig, M.C. (2005): Characterisation of glomalin as a hyphal wall component of arbuscular mycorhizal fungi. - Soil. Biol. Biochem. 37: 101-106.

[14] Eyasu, E., Scoones, J. (1998): Perspective on soil fertility change: A case study from Southern Ethiopia. - Land Degrad. and Develop. 10: 195-206.

[15] Feng, G., Zhang, F.S., Li, X.L., Tian, C.Y., Tang, C.X., Rengel, Z. (2002): Uptake of nitrogen from indigenous soil pool by cotton plant inoculated with arbuscular mycorrhizal fungi. - Commun. Soil. Sc. Plant. Anal. 33: 3825-3836.

[16] Franzluebbers, A.J., Langdale, G.W., Schomberg, H.H. (1999): Soil carbon, nitrogen, and aggregation in response to type and frequency of tillage. - Soil Sci. Soc. Am. J. 63: 349355.

[17] Gadkar, V., Rillig, M.C. (2006): The arbuscularmycorrhizal fungal protein glomalin is a putative homolog of heat shock protein. - Feder. Eur. Microbiol. Soc. 42: 65-71.

[18] Guillemin, R. (1956): Evolution de l'agriculture autochtone dans les savanes de l'Oubangui. Deuxième partie: Oubanguienne a ses origines. - Agron. Trop. 11: 143-176.

[19] Hamel, C., Dalpé, Y., Lapierre, C., Simard, R., Smith, D.L. (1994): Composition on the vesicular-arbuscular mycorrhizal fungi population in an old meadow as affected by $\mathrm{pH}$, phosphorus, and soil disturbance. - Agri. Ecosys. Environ. 49: 223-231. 
[20] Heanes, D.L. (1984): Determination of organic carbone in soils by an improved chromic acid digestion and spectrometric procedure. - Communication in soil science and plant analysis 15: 1191-1213.

[21] Helgason, T., Daniell, T.D., Husband, R., Fitter, A.H., Young, J.P.W. (1998): Plouging up the wood wide web? - Nat., 394-431.

[22] Johnson, D., Leake, J.R., Ostle, N., Ineson, P., Read, D.J. (2002): In situ ${ }^{13}$ CO2 pulselabelling of upland grassland demonstrates a rapid pathway of carbon flux from arbuscular mycorrhizal mycelia to the soil. - New. Phytol. 153: 327-334.

[23] Kabir, Z. (2005): Tillage or no-tillage: impact on mycorrhizae. - Can. J. Plant. Sci. 85: 23-29.

[24] Kathleen, K.T., Katie, M.T. (2007): Glomalin in Ecosystems. - Soil. Sci. Soc. Am. J. 71: 1257-1266.

[25] Kemper, W.D., Rosenau, R.C. (1986): Aggregate stability and size distribution. - In: Klute, A. (ed.) Methods of Soil Analysis (Part I), 425-442., Am. Soc. Agro., Madison, WI.

[26] Koutika, S.L., Hauser, S., Meuteum Kamga, J.G., Yerima, B. (2004): Comparative study of soil properties under Chromolaena odorata, Pueraria phaseoloides and Calliandra calothyrsus. - Plant Soil. 266: 315-323.

[27] Lawal, H.M., Ogunwole, J.O., Uyovbisere, E.O. (2009): Changes in soil aggregate stability and carbon sequestration mediated by land use practices in a degraded dry savanna alfisol. - Trop. Subtrop. Agroeco. 10: 423-429.

[28] Lovelock, C.E., Wright, S.F., Clark, D.A., Ruess, R.W. (2004): Stocks of glomalin produced by arbuscular mycorrhizal fungi in soil across a tropical rain forest landscape. J. Ecol. 92: 278-287.

[29] Miller, R.M., Kling, M. (2000): The importance of integration and scale in the arbuscular mycorrhizal symbiosis. - Plant. Soil. 226: 295-309.

[30] Miller, R.M., Lodge, D.J. (1997): Fungal Responses to disturbance: agriculture and forestry. - In: Wicklow, D.T., So“ derstro“ m, B.E. (eds.) The Mycota IV: Environ. Microbial. Relat. Springer, Berlin, 65-84.

[31] Newsham, K.K., Fitte, A.H., Watkinson, A.R. (1995): Arbuscular mycorrhiza protect an annual grass from root pathogenic fungi in the field. - J. Ecol. 83: 991-1000.

[32] Nichols, K.A., Wright, S.F. (2005): Comparison of glomalin and humic acid in eight native U. S. soils. - Soil. Sci. 170: 985-997.

[33] Oehl, F., Sieverding, E., Ineichen, K., Mäder, P., Boller, T., Wiemken, A. (2003): Impact of land used intensity on the species diversity of arbuscular mycorhizal fungi in agro ecosystems of central Europe. - Appl. Environ. Microbiol. 69: 2816-2824.

[34] Ogle, S.M., Breidt, F.J., Paustian, K. (2005): Agricultural management impacts on soil organic carbon storage under moist and dry climatic conditions of temperate and tropical regions. - Biogeochemistry 72: 87-121.

[35] Rillig, M.C. (2003): Arbuscular mycorrhizae and terrestrial ecosystem processes. - Ecol. Lett. 7: 740-754.

[36] Rillig, M.C. (2004): Arbuscular mycorrhizae, glomalin and soil quality. - Can. J. Soil. Sci. 84: 355-363.

[37] Rillig, M.C., Mummey, D.L. (2006): Tansley review. Mycorrhizas and soil structure. New. Phytol. 171: 41-53.

[38] Rillig, M.C., Lutgen, E.R., Ramsey, W.P., Klironomos, N.J., Gannon, E.J. (2005): Microbiota accompanying different arbuscular mycorrhizal fungal isolates influence soil aggregation. - Pedo. Biol. 49: 251-259.

[39] Rillig, M.C., Ramsey, P.W., Morris, S., Paul, E.A. (2003): Glomalin and arbuscular mycorrhizal fungi soil protein, responds to land-use change. - Plant. Soil. 253: 293-299.

[40] Rillig, M.C., Wright, S.F., Eviner, V.T. (2002): The role of Arbuscular Mycorrhizal fungi and glomalin in soil aggregation: comparing effects of five plant species. - Plant. Soil. 238: $325-333$. 
[41] Rillig, M.C., Wright, S.F., Nichols, K.A., Schmidt, W.F., Torn, M.S. (2001): Large contribution of arbuscular mycorrhizal fungi to soil carbon pools in tropical forest soils. Plant. Soil. 233: 167-177.

[42] Smith, S.E., Read, D.J. (1997): Mycorrhizal symbiosis. - Academic Press, San Diego, 126-160.

[43] Varma, A. (1998): Functions and application of arbuscular mycorrhizal fungi in arid and semi-arid soils. - In: Varma, A., Hock, B. (eds.) Mycorrhiza: Structure, Function, Molecular Biology and Biotechnology, Springer, Berlin, 521-556.

[44] Walkley, A., Black, C.A. (1934): An examination of the Degtjareff method for determining soil organic matter and a proposed modification of the chromic acid titration method. - Soil. Sc. 37: 29-38.

[45] Wright, S.F., Anderson, R.L. (2000): Aggregate stability and glomalin in alternative crop rotations for the central Great Plains. - Biol. Fertil. Soil. 31: 249-253.

[46] Wright, S.F., Upadhyaya, A. (1996): Extraction of an abundant and unusual protein from soil and comparison with hyphal protein of arbuscular mycorrhizal fungi. - Soil. Sc. 161: 575-586.

[47] Wright, S.F., Upadhyaya, A. (1998): A survey of soils for aggregate stability and glomalin, a glycoprotein produced by hyphae of arbuscular mycorrhizal fungi. - Plant. Soil. 198: 97-107.

[48] Wright, S.F., Franke-Snyder, M., Morton, J.B., Upadhyaya, A. (1996): Time-course study and partial characterization of a protein on hyphae of arbuscular mycorrhizal fungi during active colonization of roots. - Plant. Soil. 181: 193-203.

[49] Wright, S.F., Green, V.S., Cavigelli, M.A. (2007): Glomalin in aggregate size classes from three different farming systems. - Soil. Till. Res. 94: 546-549.

[50] Wright, S.F., Starr, J.L., Paltineanu, I.C. (1999): Changes in aggregate stability and concentration of glomalin during tillage management transition. - Soil. Sci. Soc. Am. J. 63: $1825-1829$.

[51] Zhu, Y.G., Miller, R.M. (2003): Carbon cycling by arbuscular mycorhizal fungi in soilplant systems. - Tr. plant. Sci. 8: 407-409. 